\title{
ERGONOMICS AND OCCUPATIONAL HEALTH IN CONSTRUCTION WORKER CERTIFICATION IN INDONESIA
}

\author{
Tuti Sumarningsih ${ }^{1}$, M. Agung Wibowo ${ }^{2}$ \\ ${ }^{1}$ Lecturer, Civil Engineering and Planning, Islamic University of Indonesia, Yogyakarta, Indonesia \\ ${ }^{2}$ Lecturer, Civil Engineering, Diponegoro University, Semarang, Indonesia
}

\begin{abstract}
In order to improve the professionalism of the construction workforce, Indonesian government through the Institute of Development Construction Services perform certification for experts named Competency Standards Expert (CSE) and skilled labor named Competency Standards Skilled (CSS) which are based on the Indonesian National Competence Standard (INCS). There are three competencies listed in INCS, namely general competency, core competencies, and competence option. In general competency containing the Occupational Health and Safety (OHS), ergonomics is not included as an element of competence that must be possessed, eventhough ergonomics is closely related to occupational health. In this study the aspects of ergonomics is examined in the form of muscle pain (musculoskeletal disorder), and remedial efforts are made by improving the work method to met the principle of ergonomics to reduce the occurrence of such complaints. The results showed that ergonomic working methods can reduce muscle pain complaints on the work of masonry, plaster, ceramic, and painting significantly.
\end{abstract}

Keywords: competence certification, INCS, ergonomics, muscle pain complaints.

\section{BACKGROUND}

The Construction Development Agency of Public Works Ministry of Indonesia noted the number of construction workers in Indonesia reached 6.3 million people. Of these $10 \%$ are experts, $30 \%$ are skilled workers, and $60 \%$ are non skilled worker. Of 630,000 experts only about 125,000 people who have certificates and of nearly 2 million skilled workers only 380,000 people were certified (Goeritno, 2013).

Under Law No. 18 of 1999 on Construction Services and Government Regulation No. 28 in 2000, a group of experts required to have a certificate of Competency Standards Expert (CSE) and a group of skilled manpower required to have a certificate of Competency Standards Skilled (CSS). These certification are based on the Indonesian National Competence Standard (INCS), given to the construction workforce through certification tests conducted by the National Construction Services Development Board.

The Competence Development and Training Construction Center of Public Works Ministry has produced more than 110 Indonesian National Competence Standard (INCS) in the field of construction that the emphasis on improving the quality and professionalism of labor to be absorbed by the construction labor market (Pratiwi, 2012). In the INCS, Occupational Health and Safety (OHS) is categorized as a general competency, which means has to be owned by anyone who wants to obtain INCS certificate. On INCS, three competence elements in the OHS are (1) recognize the signs of OHS, (2) preparing personal protective equipment (PPE), (3) using a personal protective equipment (PPE), and (4) perform first aid of the accident (FAA).

The four elements of OHS competence in INCS not covered aspects of ergonomics, eventhough ergonomics closely related to occupational safety and health. Non ergonomic way of working will cause excessive workloads so that productivity is not the maximum, it can even cause musculoskeletal disorder/muscle injury (Muslimah, et al, 2006).

In the Law No. 23 of 1992 on Health, in Article 23 concerning occupational health, it is mentioned that effort to occupational health shall be held at each workplace, especially the workplace that have huge health hazard for workers, so that workers can work in a healthy without endangering their self and the people around them, to obtain optimal productivity, in line with labor protection program. Riyadina (2008) in his study of industrial workers in the Industrial Area Pulogadung, Jakarta, with 950 samples found that complaints of muscle pain experienced by a row of which the highest is the garment industry workers $(65.2 \%)$, the printing industry $(63 \%)$ and construction industry $(60 \%)$.

\section{RESEARCH PURPOSES}

The purposes of this study are :

[1]. Knowing how not ergonomic work method cause problems on the health of construction workers.

[2]. Improving the health of construction workers by applying ergonomic work method.

\section{LITERATURE REVIEW}

Ergonomics is the science, art and technology to harmonize the tools, methods and work environment of the human capabilities and limitations in activities and work, so that people can work optimally without the bad influence of his 
work (Tarwaka et al., 2004; Abdillah, 2013). Adverse effects of the activity or occupation by humans include muscle pain until the damage to the joints, ligaments, and tendons called musculoskeletal disorders or MSDs (Grandjean, 1993; Fatimah, 2012; Yusnani, 2012).

Skeletal (frame) muscle including the muscles of the neck, shoulders, arms, hands, fingers, back, waist, and bottom muscles (legs). Most injuries suffered by workers is lower back muscles (low back pain / LBP). Complaints skeletal muscle occurs due to excessive muscle contraction caused by heavy workload in long loading time. If muscle contraction exceeds $20 \%$ of maximum muscle strength, blood circulation to the muscles is reduced in proportion to the level of contraction that influenced by the amount of force to be deployed. Decreased oxygen supply to the muscles cause carbohydrate metabolism disturbed and as a result there has inhibited the accumulation of lactic acid that causes muscle pain (Suma'mur, 1989; Fatimah, 2012).

Musculoskeletal disorders caused by three things: (1) excessive stretching, (2) repetitive activities, and (3) working position is not natural. Not natural work position is working position that causes the position of the body parts away from the natural position, such as the movement of hands raised, backs bent, and head raised. The more distant parts of the body position of the center of gravity of the body, the higher the risk of skeletal muscle complaints.

One instrument to determine the parts of muscle experiencing musculoskeletal complaints is Nordic Body Map/NBM (Corlett, 1992 in Tarwaka, et al, 2004) as shown in Figure 1. By looking at and analyzing the body map (NBM), can be known types muscle complaints experienced by workers, and corrective action needed.

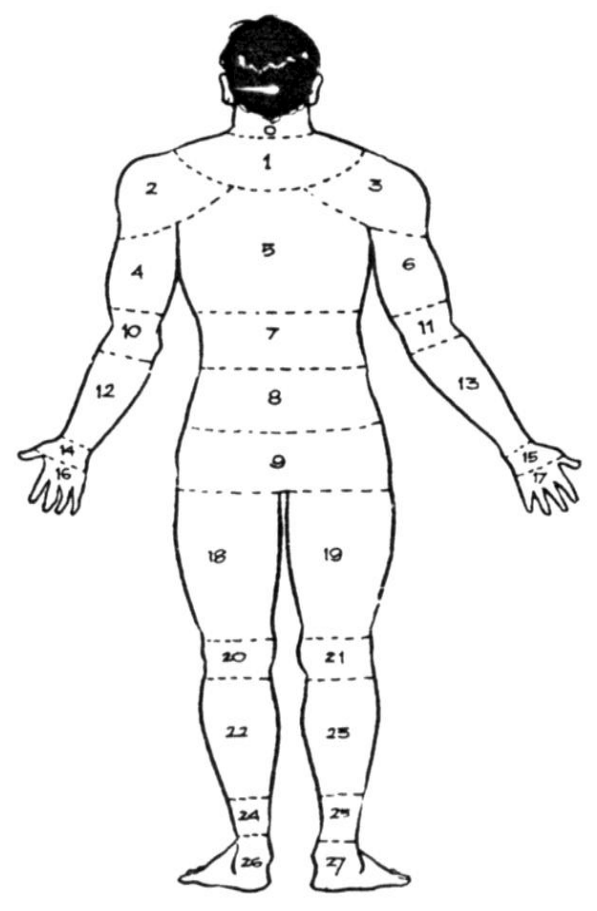

Figure 1. Nordic Body Map (Corlett, 1992)
Muscle injury can be caused by wrong working position or wrong way to lift weights. In the construction project workers perform various work in a standing position, sitting, bending, or squat. Lifting and carrying the load is very much types of work performed by construction workers. According Sutalaksana (2000) quoted Tarwaka, et al. (2004), standing is alert position physically and mentally, so that workers can work faster, stronger, and meticulous. Nevertheless standing position more tiring work, and the energy expended $10 \%$ - $15 \%$ compared to sitting. Working in a standing position can cause a buildup of blood and body fluids in the feet, and this will increase if the worker does not wearing shoes/footwear in appropriate shape and size (Santoso, 2004).

Grandjean (1993) found work in a sitting position has two advantages that reduce the load on feet, and reduce energy consumption for blood circulation. However, sitting work position for too long can cause abdominal muscles become soft and curved spine so that workers feel more tired (Tarwaka, et al., 2004). In the sitting position, skeletal muscle and spine (vertebrae), especially in the waist should be held down by the back of the chair in order to avoid back pain. According to Nurmianto (1998) cited by Santoso (2004), the pressure on the spine will increase to $140 \%$ when sitting in a tense and rigid position, and $190 \%$ when sitting is done by bending forward.

Squatting and bending working position is a position that is unnatural and will lead to high fatigue caused due to static loads. Working with bending position of the body without supporting material requires the physical energy of 3 $\mathrm{kcal} / \mathrm{min}$ as shown in Figure 2. Working with squatting position or bending the knee with partial body weight supported by one hand requires less energy, ie $2 \mathrm{Kcal} / \mathrm{min}$ (McCormick, 1979; Wignjosoebroto, 2003).

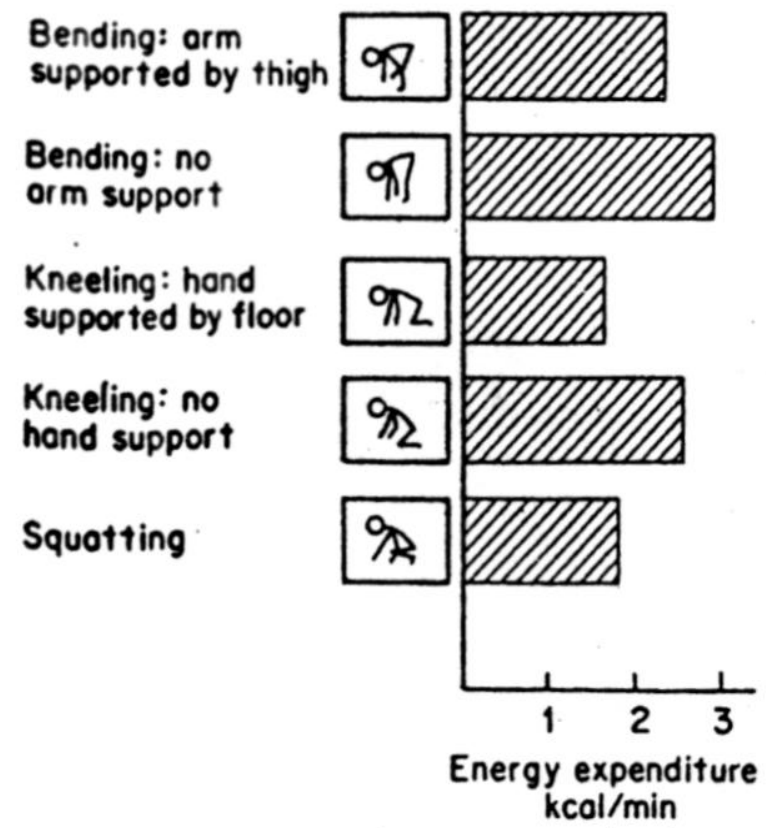

Figure 2. Energy Required At Work Position Bending and Squat (McCormick, 1979) 
The position of the body when lifting weights also determine the type of muscle that works as well as injuries that may occur (Oborne, 1987). Figure 3 shows three ways of clicking weights. Figure (a) from squatting position the load is lifted by lifting the thighs. By this way the most over worked muscle is the muscle of the thigh. Figure (b) from a squatting position, backs lifted first and the load is lifted. Here the thigh muscles and back muscles work together. In Figure (c) a load lifted from a standing position by means of bending the back. In this way the whole load is supported by the back muscles.

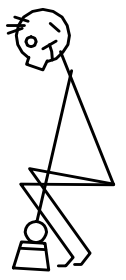

(a)

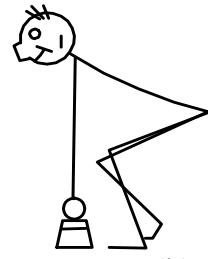

(b)

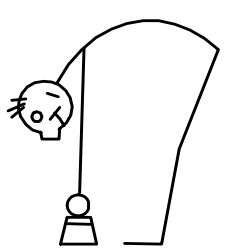

(c)
Figure 3. Three ways to lifting weights

Wrong way of lifting weights will cause pain in the vertebrae. When someone lifting weights with a bow, a large pressure occurs at the waist as a result of force lever (Suma'mur, 1989). On the activity of lifting and carrying the burden should be placed as close as possible to the vertical line of gravity of the body. Thus the moment of force does not occur in the body and can avoid static muscle activity unnecessary.

The load on the spine increases from top to bottom, and the heaviest load occurs in the joints of the lumbar spine. The wayof lifting weights with the spine slant will cause heavy pressure on the joints of the spine, which will result in spinal pain (back pain). The effect of pressure on the vertebrae caused by lifting load is illustrated in Figure 4.

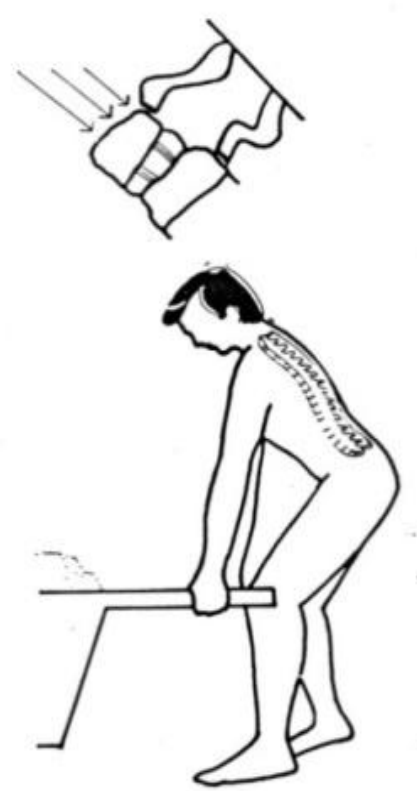

Wrong

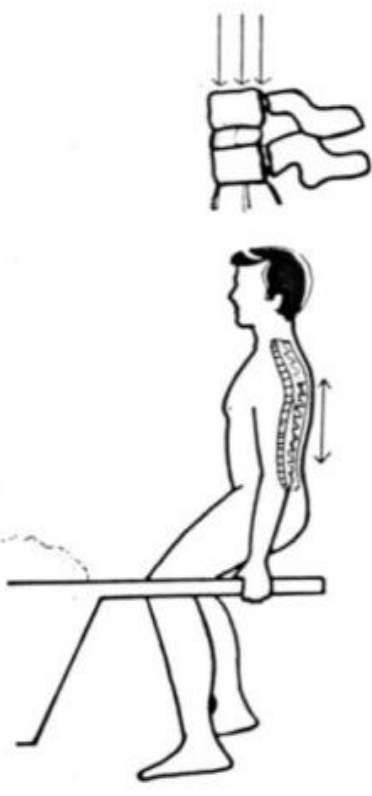

Right
Figure 4. The way of lifting load and the pressure effect on the vertebrae
Carrying load by wearing a sling is better than carrying the load on the back, because there will cause a static contraction in the muscles of the abdomen. Carrying a light load on the right and left hand is better than carrying a heavy load with one hand. Carrying heavy loads on both hands is not recommended because it will make the muscles of the shoulder and upper arm stretched. Weight limit that is allowed for the continuous carrying is $15-18 \mathrm{~kg}$ for adult men and $10 \mathrm{~kg}$ for adult woman (Suma'mur, 1989).

\section{RESEARCH METHODS}

The study was conducted in Yogyakarta, Indonesia, with the object of study are 30 masonry and plaster workers, 22 ceramic workers, and 24 painting workers. Research for masonry and plaster work was conducted over 11 months on the construction project of Panembahan Senopati Bantul District Hospital, the construction of College Building of Yogyakarta State University, and the construction of Religion Yogyakarta Courthouse. Research for ceramic work was conducted in 2011 in the construction of the Central Library of Indonesian Islamic University, and research for the painting work was carried out in May 2013 in several housing in Yogyakarta.

Data were collected by recording the workers by handy video camera to learn the position and movement of the worker's body. To determine muscle complaints occur, the workers are shown pictures of Nordic Body Map (NBM) and they were asked to provide an assessment in accordance with the given criteria, namely the LP (Little Pain = 1), P $($ Pain $=2)$, and VP (Very Pain $=3$ ). This value is then averaged to obtain a general overview of the complaints musculoskeletal experienced workers.

\section{RESULTS AND ANALYSIS}

The results of interviews with workers using reference Nordic Body Map (Figure 1) shown that the average worker is experiencing fatigue and muscle pain in the waist, back, neck, upper arms, thighs, and calves. Fatigue is felt after worker working with a squatting position and bent in a long time. Workers with over 40 years of age tend to have more muscle complaints on waist, back, neck, and shoulders.

To reduce fatigue due to working positions that are not natural, improvements is made by put the material on the table or pedestal, so that when the work field has reached a height of 0.75 meters above and the workers have to work in a standing position, the workers do not have to bend down to pick up the material. The layout of the material is also arranged by applying the principles of motion economy. In the work of masonry, brick placed on the left and mortar on the right, so that workers do not need to rotate the body at the time of pick up and put up a brick. Likewise, the method applied in plaster, ceramic, and painting work.

If the height of the working field has more than 1.5 meters above ground level or work platform, the worker must reach upward to reach areas of work. Reaching upward movement in addition to inefficient, requiring more power, will also 
lead to a higher muscle fatigue in particular bicep. Based on research by Tichaeur (in Grandjean, 1993), optimal results with minimal energy requirements is achieved at the position of the upper arm form an angle of $8^{\circ}-23^{\circ}$ with the body.

If the field work has reached a height of about 1.50 meters, then the worker must lift the arm higher, which results in the upper arm form an angle greater than $23^{\circ}$. Thus the height of the field work must be limited so that workers can still work comfortably and well productivity.

Figure 5 shows a pair of ceramic workers working with a squatting position that will cause fatigue in the muscles of the back, hips, thighs, and calves. Squatting position is improved by giving a pedestal sitting so that the workers body weight can be supported evenly and muscle pain can be reduced (Figure 6).

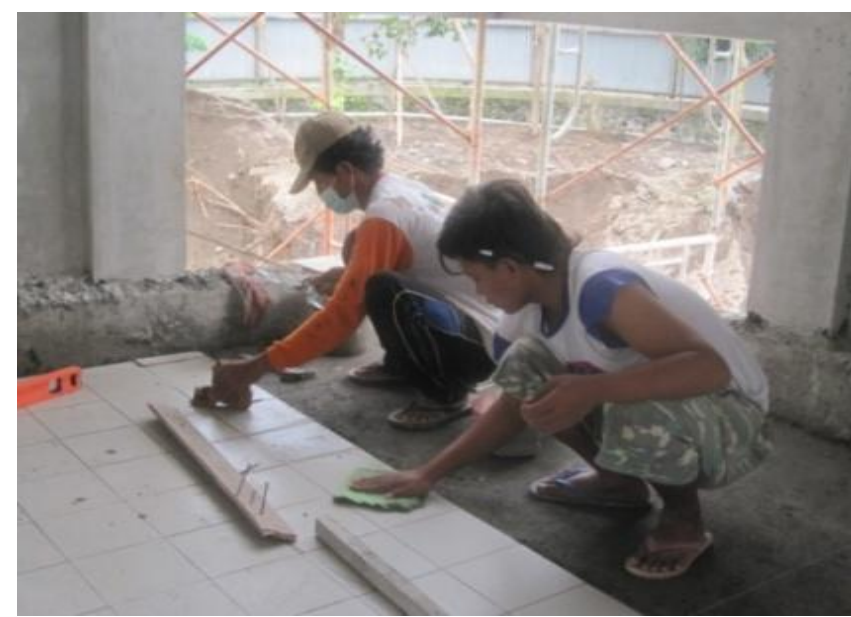

Figure 5. Floor Ceramic Work

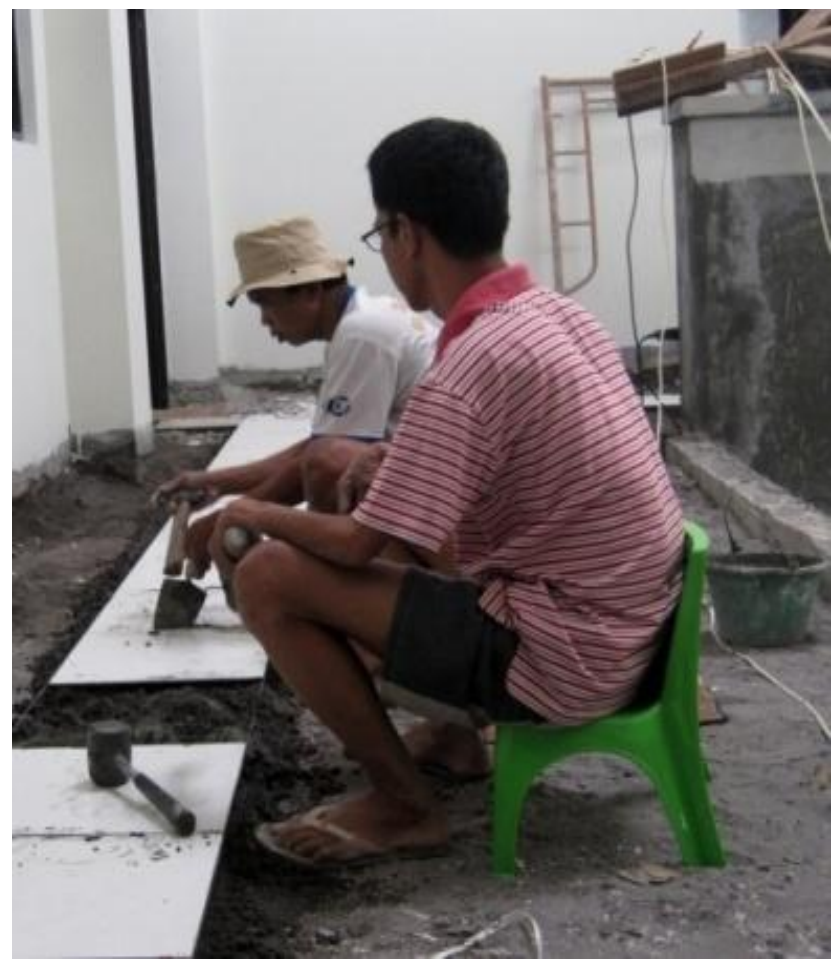

Figure 6. Pedestal SittingTo Flatten Body Burden
For standing position, the material is placed on the pedestal (Figure 7). The material is placed on the right and left of the workers, so that workers can work by activating both hand sequally, without bending or twisting the body to take the required material.

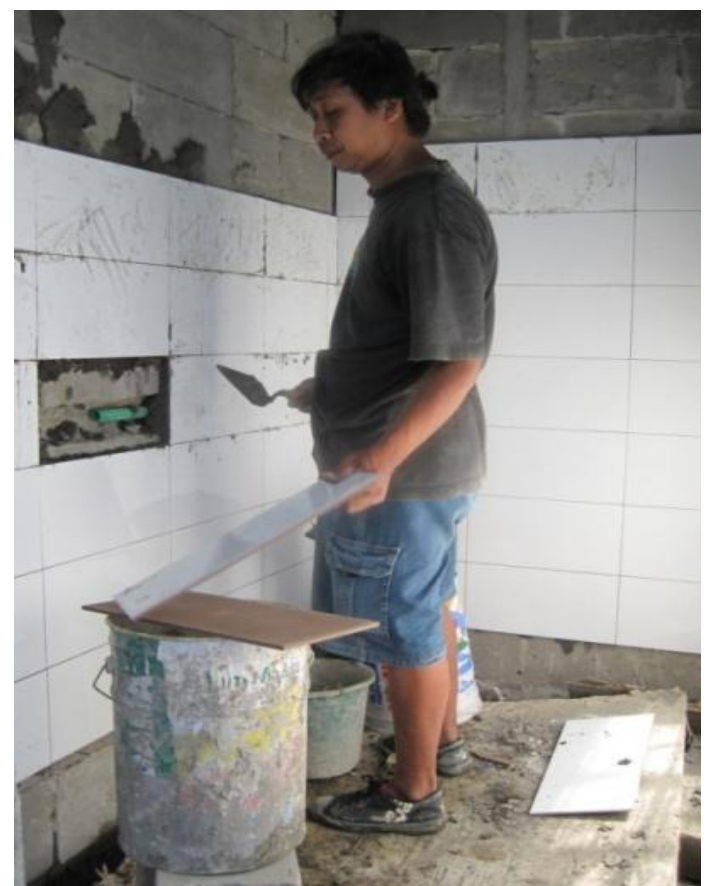

Figure 7. The ceramics dan mortar are placed on the pedestal

In painting work, the most uncomfortable position of the body is the ceiling painting, because the position of the head should always up so muscular number 1 (neck) experienced fatigue. Muscles numbers 2 and 3 (shoulder) and muscle number 4 and 6 (arm) also experience fatigue due to the position of the arm is always lifted up and withstand load (Figure 8). Improving method is done by placing paint on top of the pedestal so that the worker hands do not support the weight, and workers standing on a solid foundation so that the position of the body is more stable. The body facing the field are painted so that workers do not need to rotate the body that lead to back and waist muscles twisted (Figure 9).

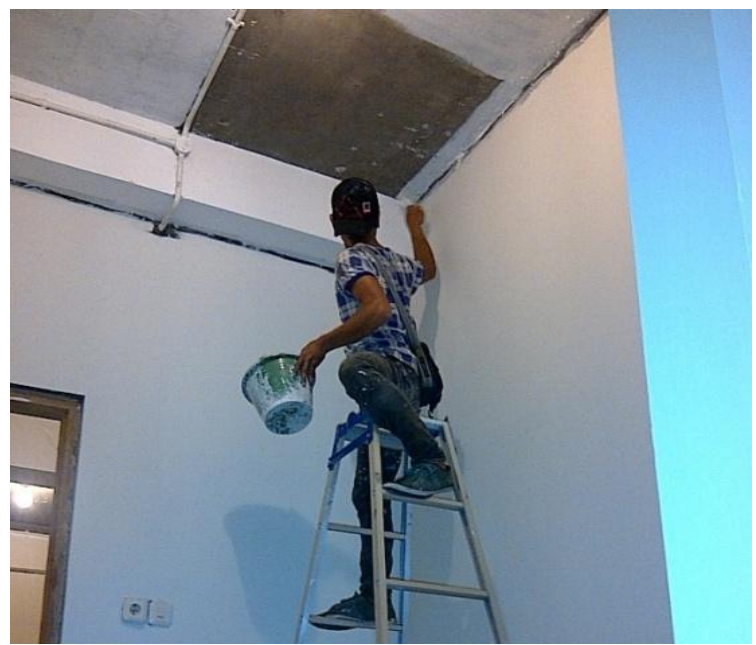

Figure 8. Body Position Not Natural 


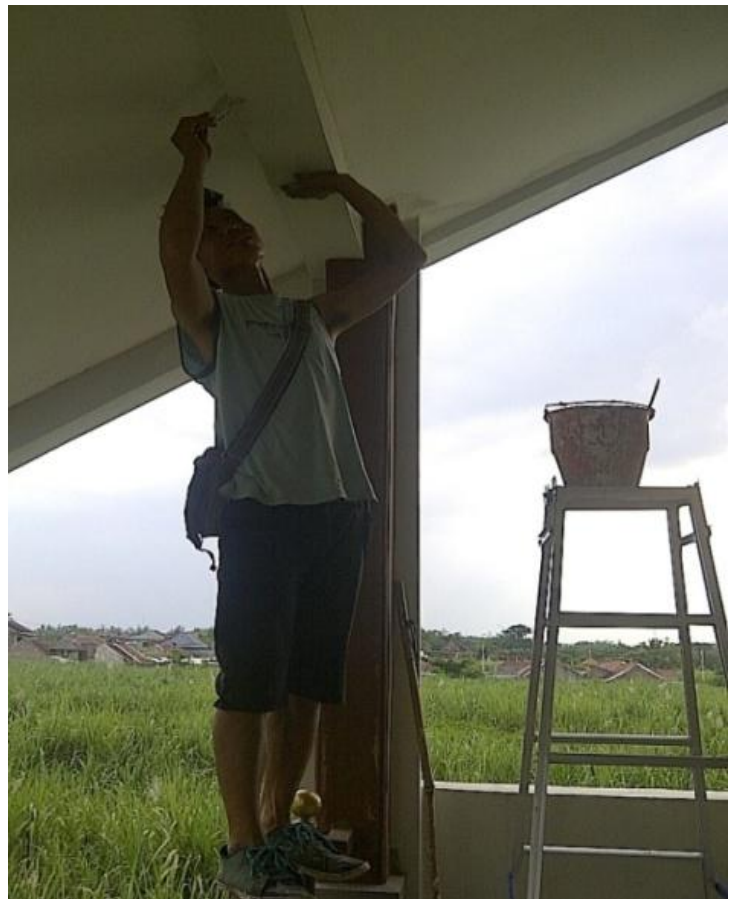

Figure 9. Body Position Without Overload
Musculoskeletal grievances felt by workers is not the same, influenced by age, body weight, body size, smoking habits, physical fitness, physical strength, working position, and the length of their work at the working position, which is unnatural. Summary of complaints due to musculoskeletal experienced by workers on the masonry work, plaster work, ceramic work, and painting work on the initial conditions and the improve methods, as well as a decrease in complaints due to improved working methods shown in Table 1

Table 1. Muscle Pain ComplaintsBy Workers

\begin{tabular}{|c|c|c|c|c|c|c|c|c|c|c|c|}
\hline \multirow[b]{2}{*}{$\begin{array}{l}\text { Type } \\
\text { The } \\
\text { Work }\end{array}$} & \multirow[b]{2}{*}{ Working Conditions } & \multicolumn{10}{|c|}{ Complaints On Any Type Muscles } \\
\hline & & $\begin{array}{c}\text { (1) } \\
\text { Neck }\end{array}$ & $\begin{array}{c}(2 \& 3) \\
\text { Shoulder }\end{array}$ & $\begin{array}{l}(4 \& 6) \\
\text { Sleeve }\end{array}$ & $\begin{array}{c}(5) \\
\text { Backs }\end{array}$ & $\begin{array}{c}\text { (7) } \\
\text { Waist }\end{array}$ & $\begin{array}{c}(8) \\
\text { Pelvis }\end{array}$ & $\begin{array}{c}\text { (9) } \\
\text { Pelvis }\end{array}$ & $\begin{array}{c}\text { (18\&19) } \\
\text { Thigh }\end{array}$ & $\begin{array}{c}(20 \& 21) \\
\text { Knee }\end{array}$ & $\begin{array}{c}(22 \& 23) \\
\text { Calf }\end{array}$ \\
\hline \multirow{3}{*}{$\begin{array}{c}\text { Bricks } \\
\& \\
\text { Plaster }\end{array}$} & Initial Condition & 0,56 & 0,16 & 1,26 & 1,20 & 1,56 & 1,76 & 0,13 & 0,43 & 1,03 & - \\
\hline & Improve Method & 0,22 & 0,04 & 0,26 & 0,13 & 0,56 & 0,86 & 0,04 & 0,17 & 0,30 & - \\
\hline & Complaints Decrease(\%) & 64,3 & 75,0 & 77,6 & 85,7 & 72,4 & 60,2 & 76,9 & 55,8 & 58,2 & - \\
\hline \multirow{3}{*}{ Ceramic } & Initial Condition & 0,45 & 0,95 & 0,59 & 1,64 & 1,77 & 1,18 & 1,82 & 0,95 & 1,14 & 0,86 \\
\hline & InproveMethod & 0,23 & 0,63 & 0,27 & 0,41 & 0,45 & 0,36 & 0,68 & 0,32 & 0,27 & 0,36 \\
\hline & Complaints Decrease (\%) & 52,3 & 34,7 & 51,8 & 74,4 & 74,8 & 68,4 & 63,0 & 68,4 & 74,5 & 58,1 \\
\hline \multirow{3}{*}{ Painting } & Initial Condition & 2,13 & 1,87 & 1,66 & 0,96 & 0,71 & 0,83 & 0,66 & 0,75 & 0.54 & - \\
\hline & Improve Method & 1,00 & 0,58 & 0,67 & 0,33 & 0,37 & 0,54 & 0,38 & 0,42 & 0,25 & - \\
\hline & Complaints Decrease (\%) & 52,3 & 68,8 & 59,8 & 67,8 & 45,6 & 36,8 & 40,2 & 44,8 & 52,1 & - \\
\hline
\end{tabular}

From Table 1 we can notice a significant decline in muscle complaints. Three types of muscle complaints that most often found on the masonry and plaster work are muscular number 4 and 6 (arm), muscle number 5 (back), muscle number 7 (waist), and muscle number 8 (pelvis). Decrease complaint after improve method is applied are : on the arm muscles $77.6 \%$, back muscles $85.7 \%$, lumbar muscle $72.4 \%$, and pelvic muscles $60.22 \%$.

In the work of ceramic, the highest muscle complaints occur in the muscles number 5 (back), muscle number 7 (waist), muscle number 8 (pelvis), muscle number 9 (pelvis), and muscles number 20 and 21 (knee). Decrease complaint to the back muscles after being applied improve method amounted to $74.4 \%$, waist muscles $74.8 \%$, pelvic muscles $68.4 \%$ and and knee muscles63\%, $74.5 \%$.

In painting work, most muscle complaint is muscle number 1 (neck), muscle number 2 and 3 (shoulder), muscle number 4 and 6 (arm), and muscle number 5 (back). Decrease complaint after repair method is applied on the neck muscles is at $52.3 \%$, shoulder muscles $68.8 \%$, arm muscles $59.8 \%$, and back muscles $67.8 \%$. 
From interviews with workers, it is known that in the initial conditions before the improve method applied, many workers complain of muscle pain (musculoskeletal disorder)

in the muscles of the back, waist, hips, thighs, calves, and knees with the level of complaints 'little pain', 'pain', and 'very pain'. This indicates that the working methods used is not good when viewed from the aspect of ergonomics. After improved work method applied by putting material on the table/footstool and adjust the material in order to achieve economic movement, also provide pedestal sitting to avoid squatting position, muscle pain reduced.

Of the 10 complaints of workers perceived muscle as shown in Table 1, shown 5 complaints most widely felt in the work of masonry and plaster, ceramic, and painting. Decreased muscle pain complaints are shown in Table 2. In this case the value $1=$ a little pain, 2 = pain, and $3=$ very pain.

Table 2. Decrease Complaints of Musculoskeletal After Improve Work Method Applied

\begin{tabular}{|c|c|c|c|c|}
\hline \multirow[b]{2}{*}{ Type of The Work } & \multirow[b]{2}{*}{ Muscle Type } & \multicolumn{3}{|c|}{ Complaints Musculoskeletal } \\
\hline & & $\begin{array}{c}\text { Initial } \\
\text { Condition }\end{array}$ & $\begin{array}{c}\text { Improve } \\
\text { Work Method }\end{array}$ & Decrease \\
\hline \multirow{5}{*}{$\begin{array}{l}\text { Bricks \& } \\
\text { Plaster Work }\end{array}$} & Sleeve & 1,26 & 0,26 & $77,6 \%$ \\
\hline & Back & 1,20 & 0,13 & $85,7 \%$ \\
\hline & Waist & 1,56 & 0,56 & $72,4 \%$ \\
\hline & Pelvis & 1,76 & 0,86 & $60,2 \%$ \\
\hline & Knee & 1,03 & 0,30 & $58,2 \%$ \\
\hline \multirow{5}{*}{ Ceramic Work } & Back & 1,64 & 0,41 & $74,4 \%$ \\
\hline & Waist & 1,77 & 0,45 & $74,8 \%$ \\
\hline & Pelvis Above & 1,18 & 0,36 & $68,4 \%$ \\
\hline & Pelvis down & 1,82 & 0,68 & $63,0 \%$ \\
\hline & Knee & 1,14 & 0,27 & $74,5 \%$ \\
\hline \multirow{4}{*}{ Painting Work } & Neck & 2,13 & 1,00 & $52,3 \%$ \\
\hline & Shoulder & 1,87 & 0,58 & $68,8 \%$ \\
\hline & Sleeve & 1,66 & 0,67 & $59,8 \%$ \\
\hline & Back & 0,96 & 0,33 & $67,8 \%$ \\
\hline
\end{tabular}

Application of the principles of ergonomics in the work place and in the workings will make workers can work safely, comfortably, efficiently and effectively, in order to achieve high productivity. In addition to quality, cost and time (which is closely linked to productivity), construction project objectives also include Occupational Health and Safety (OHS). Occupational Health and Safety is the rights of workers, and it is set in Act No. 1 of 1970.

At this time certification in OHS Construction Expert already implemented, which is an integral part of the construction labor certification in Indonesia conducted by the National Construction Services Development Board. Understanding of ergonomics should be one of the competencies included in the codification of competence OHS construction field. In the Indonesian National Competence Standard (INCS), the implementation of Occupational Health and Safety (OHS) is categorized as a general competency, which means it must be owned by anyone who wants to obtain a certificate INCS. However, the ergonomics are not logged in competence elements. When viewed on INCS, the four elements in the OHS competence are (1) recognize the signs OHS, (2) preparing personal protective equipment (PPE), (3) using a self protective equipment (PPE), and (4) perform first aid the accident (FAA).

Besides not include ergonomics in the codification of competence, INCS also not incorporate productivity as their competency in the labor certification. Supposedly, to obtain a Competency Standards Skilled (CSS), besides having the ability to do a certain job fields, one also must have a certain level of productivity in the work. Without productivity standards that must be met in a labor certification, company/ party service users will employ certified workforce has no guarantee of how long it takes by the labor force to finish the job. Service users also can not make a claim if it turns a certified workforce has low productivity, although qualified in terms of quality. In other words, the INCS only applying qualitative standards, but do not have a quantitative standard. 


\section{CONCLUSION}

[1]. Work method that does not pay attention to ergonomic principles lead to worker health problems, namely muscle pain (musculosceletal disorder) at various levels of severity.

[2]. By improving work method to meet ergonomic principles, muscle pain experienced by workers decreased significantly.

\section{ADVICE AND FEEDBACK}

Company of construction is expected to pay more attention to the health of construction workers by giving understanding to the field supervisors, foremen, and workers about the importance of applying the principles of ergonomics to prevent health problems of workers particularly those related to muscle pain.

In the codification of competence INCS ergonomic aspects should be included and be an important part of general competence with regard to the implementation of Occupational Health and Safety (OHS).

\section{ACKNOWLEDGEMENT}

The author gratefully acknowledge Islamic Indonesian University (UII) for giving financial support for this research project.

\section{REFERENCES:}

[1]. Abdillah (2013) “Analisis Postur Kerja Dengan Metode Rapid Upper Limb Assesment (RULA) Pada Pekerja Kuli Angkut Buah di "Agen Ridho Illahi”" Pasar Johar Kota Semarang”, Jurnal Kesehatan Masyarakat, Vol. 2, No. 1, hal. 1 - 10, Fakultas Kesehatan Masyarakat Universitas Diponegoro, Semarang.

[2]. Fatimah (2012) "Analisis Faktor-faktor Ergonomi Yang Berpengaruh Terhadap Keluhan Musculosceletal", Jurnal Teknik Industri, Vol.1 No.1, Juni, hal. 37 - 45, Jurusan Teknik Industri Universitas Bung Hatta, Padang.

[3]. Goeritno, B. (2013) "BP Konstruksi Targetkan 3,78 Juta Tenaga Terampil”, www.aabi.or.id , down loaded 16 Juni 2013

[4]. Grandjean, E. (1993) Fitting the Task to the Man, 4th ed, Taylor \& Francis Inc., London.

[5]. McCormick, EJ (1979) Human Factors in Engineering and Design, McGraw-Hill, New Delhi.

[6]. Muslimah, dkk. (2006) "Analisis Manual Material Handling Menggunakan NIOSH Equation", Jurnal Ilmiah Teknik Industri, Vol. 5 No. 2, Desember, 53 60, Jurusan Teknik Industri Universitas Muhammadiyah Surakarta.

[7]. Pratiwi (2012) "Sertifikasi Tenaga Kerja Konstruksi Sebagai Unsur Pendukung Pembangunan Infrastuktur", Makalah Seminar, cyber.unissula.ac.id/journal/ dosen, down loaded 23 Maret 2014

[8]. Riyadina, dkk. (2008) "Keluhan Nyeri
Muskuloskeletal pada Pekerja Industri di Kawasan Industri Pulo Gadung Jakarta”, Majalah Kedokteran Indonesia, Vol. 58, No. 1, Januari, hal. 8-12.

[9]. Santosa, G. (2004) "Ergonomi, Manusia, Peralatan, dan Lingkungan", Prestasi Pustaka, Jakarta.

[10]. Suma'mur (1989) "Ergonomi Untuk Produktivitas Kerja”, Inti Idayu Press, Jakarta.

[11]. Tarwaka, et al. (2004) "Ergonomi Untuk Keselamatan, Kesehatan Kerja dan Produktivitas", Uniba Press, Surakarta.

[12]. Wignjosoebroto (2003) "Ergonomi, Studi Gerak dan Waktu, Teknik Analisis Untuk Peningkatan Produktivitas Kerja”, Guna Widya, Surabaya.

[13]. Yusnani, dkk. (2012) "Perbedaan Keluhan Muskuloskeletal Sebelum dan Sesudah Pemberian Perlakuan Latihan Pregangan Pada Petugas Kesehatan Gigi di Puskesmas Kecamatan Medan Area”, jurnal.usu.ac.id, diunduh tanggal 23 Maret 2014.

\section{BIOGRAPHIES}

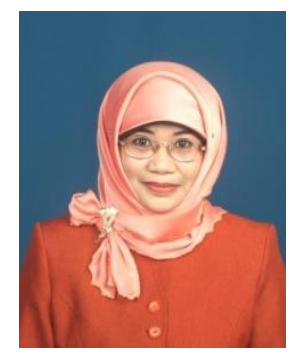

Tuti Sumarningsih is a lecturer at the Islamic University of Indonesia since 1987. She pursue the field of Construction Management and has been teaching for years in Project Management, Quality Management, and Disaster Risk Management. At this time she is pursuing doctoral studies in the field of Construction Management at the Diponegoro University, Semarang, Indonesia.

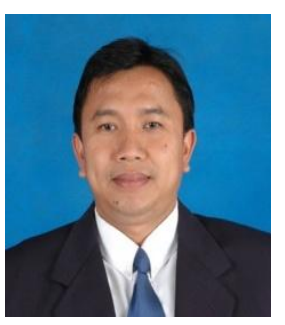

M. Agung Wibowo is a lecturer at the Faculty of Civil Engineering, Diponegoro University, Semarang, Indonesia. He holds a Master of Science and Doctor of Philosophy from Nottingham University, UK. He is an expert in the field of Construction Management. Many scientific papers have published in various international events. 